\title{
Are Chinese Students Really Quiet, Passive and Surface Learners? - A Cultural Studies Perspective
}

\author{
Jinyan Huang (College of Education of Niagara University) \\ Peter Alexander Cowden (College of Education of Niagara University)
}

\begin{abstract}
Research has indicated that Chinese students experience considerable challenges in their academic studies at North American universities. This paper explores Chinese students' academic learning through cultural studies perspectives by examining the concept of identity; cultural and linguistic context; Chinese students as quiet and passive learners; different classroom teaching methods experienced in both cultures; surface learners vs. deep learners; different culture worlds; and the concept of social communicative competence. It is argued that quiet, passive and surface learners are perhaps incorrect descriptors of Chinese students who are studying at North American Universities. Important educational implications are discussed.
\end{abstract}

\begin{abstract}
Résumé
Plusieurs recherches montrent que les étudiants chinois doivent relever des défis considérables quand ils étudient dans des universités nord américaines. Le but de cet article est d'explorer l'apprentissage académique des étudiants chinois à partir d'une vision d'études culturelles. Ceci nous mènera à examiner le concept d'identité, de contexte culturel et linguistique, ainsi que des notions telles que le calme et la passivité des étudiants chinois, les différences entre méthodologies d'enseignement dans les deux cultures, les apprenants superficiels en opposition avec les apprenants réfléchis, les différences culturelles, et enfin, le concept de compétence communicative sociale. description des étudiants chinois comme étant des apprenants calmes, passifs et superficiels sont des descripteurs qui peuvent s'avérer incorrects si l'on prend en compte toutes les implications culturelles qui seront discutées dans cet article.
\end{abstract}

\section{INTRODUCTION}

Chinese students from the People's of China are the largest single group of English-as-a-second-language (ESL) students studying at North American universities (Canadian Bureau for International Education, 2002; Institute of International Education, 2001). Furthermore, approximately eighty percent of the Chinese students currently studying at North American universities are graduate students. They generally have received their undergraduate education in China prior to commencing graduate school in North America. The academic learning of Chinese students at North American universities has important implications for university administrators and other educators.

Research with ESL students studying at North American universities has indicated that Chinese students experience considerable challenges in their academic studies (Chen, 1999; Feng, 1991; Huang, 2004, 2005, 2006; Huang \& Klinger, 2006; Liu, 1994; Sun \& Chen, 1997; Upton, 1989; Zhong, 1996). All 
these studies identified both linguistic and cultural factors that affect Chinese students' academic studies: their unfamiliarity with the North American culture; their lack of North American academic background; their lack of academic study skills, and their inadequate English proficiency. But none of them has examined Chinese students' academic learning through the perspectives of cultural studies, which examines the implications of the social, cultural, philosophical, historical and political contexts for education from a very critical perspective.

Chinese students are from a very different cultural environment and educational system. They are often stereotyped as quiet, passive and surface learners by North American instructors (Samuelowicz, 1987; Pratt \& Wong, 1999). We would argue that this is a wrong and distorted identity of Chinese students. We content that they are not offered equal opportunities both in and outside North American classrooms and they are treated as outsiders or "others".

\section{THE CONCEPT OF IDENTITY}

Taylor (1992) defines identity as a person's understanding of who s/he is, of her/his fundamental defining characteristics as a human being. And how one defines oneself is partly dependent on the recognition, mis-recognition, or absence of recognition by others. "Non-recognition or mis-recognition can inflict harm, can be a form of oppression, imprisoning someone in a false, distorted and reduced mode of being" (Taylor, 1992, p. 25).

Contemporary conceptions of identity are influenced by postmodern/poststructural / postcolonial writers who reject theoretical discourses which conceptualize identity as a state (which can be measured) rather than as process (Ghosh, 2000). Earlier discussions of identity were located in the area of personality as "a person's essential, continuous self, the internal, subjective concept of oneself as an individual" (Reber, 1985, p. 341). Social identity research challenged this individualistic frame and subjective definition of the notion of identity as a stabilized factor, an essential personality trait.

Identity is no longer seen as a static, unitary trait. It is now seen as being formed in social processes (Krugly-Smolska, 1997). People construct their identities within the social framework. As such, identities are constantly shifting and renegotiable, and the search for new/modified identities, therefore, is a coping mechanism in the confusion caused by migration and global changes. At the individual level, those who identify with a group can redefine the meaning and norms of group identity (Ghosh, 2000).

Although identity is not formed only within race, gender, nationality, class, and sexual preference, those are very important in forming one's identity (Krugly-Smolska, 1997). Each person has many "social identities" such as ethnic, 
sexual, and class identities that develop meaning in people's lives both at the ideological/political and social/cultural level. People's multiple identities are not apparent in all contexts and represent different spheres of reality in everyday life. Different ones are important at different times (Ghosh, 2000).

\section{CHINESE STUDENTS AND THEIR IDENTITY}

Two things decide Chinese students' identity: how they identify themselves, and their identification by North Americans. According to Ghosh (2000), how Chinese students identify themselves should be based upon their experiences of the past and present social, cultural and economic relations; and how North Americans define them is influenced by how their differences from the "norm" are viewed and constructed. The norm is based on the physical, cultural and value attributes of the majority or dominant North American culture.

The experiences of Chinese students, particularly how they are perceived or identified at North American universities and among their North American peers, have a direct impact on the construction of their identity. At North American universities, administrative people, professors, and staff members are all involved in influencing the construction of Chinese students' identity by the way they interact with them and the manner in which they deal with conflicts. What the professor expects, the invisible biases and hidden inequalities in classroom interactions influence how Chinese students perceive themselves.

\section{Chinese students as surface learners}

Marton and Saljo (1976) conducted the early studies on Chinese students' learning approaches. They compared Chinese students with Westerns learners and identified the former as surface learners and the latter as deep learners. In their research they simply asked the students to read some written passages and then describe what they did while reading the passages. Chinese students, in their study, reported trying to memorize the phrases or words used by the author. More recently several studies indicate that Western instructors believe that Chinese students tend to take a shallow approach to learning, they want to rote learn and do not want to think (Samuelowicz, 1987; Pratt \& Wong, 1999).

Actually these researchers just misperceive Chinese approaches to learning. What they do is just simply ask Chinese students to read some passages or answer some questions and then classify them as surface learners (a very "surface" research approach). As a result, many Western educators now believe that Chinese students engage in memorization and are not interested in deep understanding (Pratt \& Wong, 1999). We would argue that Chinese students use memorization as a path to understanding and vice versa. Memorization and 
understanding are related to each other. Chinese students may engage in strategies that appear to be surface oriented but actually are deep oriented (Biggs, 1987; Kember \& Gow, 1991; Marton, Dall’Alba, \& Kun, 1996).

\section{Chinese students as quiet and passive learners}

Chinese students are frequently characterized as passive learners at North American classrooms (Chen, 1985; Feng, 1991; Upton, 1989). They are not actively asking and answering questions, and participating in classroom discussions. We would argue that North American classrooms did not produce a desirable learning environment for Chinese students.

First, North American classrooms produce an informal and disrespectful learning environment. Chinese students often feel uncomfortable with the students' behaviors in North American classrooms. They have a negative reaction toward North American students' behaviors (Chen, 1985; Upton, 1989). Students can be late for class. They often ask the teacher questions or make jokes in class. All these behaviors are considered rude and disrespectful in Chinese classrooms. In North American classrooms students can challenge the teacher at any time by interrupting the teachers and ask them questions, which makes Chinese students feel that students do not show any respect for their teachers, because in Chinese culture teachers are considered as authorities and they should gain respect from their students. So this learning atmosphere stops Chinese students from active learning in North American classrooms.

Second, North American culture can result in exclusion of Chinese students from North Americans in the classrooms. Due to their different cultural background, Chinese students have not familiarized themselves with North American culture. North American culture has become a major source for demonstrating examples, discussing topics, and cheerful jokes in the classroom. Undoubtedly, Chinese students have problems understanding and participating in classroom interactions. They are as a result treated unequally to their North American peers.

Finally, Chinese students are wrongly labeled as passive or inactive learners in North American classrooms. They are "passive” perhaps because they have no access to classroom interactions. They are "inactive" perhaps because they are ignored or forgotten by the North Americans in the classroom. Thus they are treated as a different group of "others" in the classroom: quiet, passive, inactive, and struggling students. 


\section{A FALSE AND DISTORTED IDENTITY}

Chinese students at North American universities are often stereotyped as quiet, passive, surface, reserved and non-assertive, which is a wrong and distorted identity. This is related to a larger problem of "othering," the tendency to perceive outsiders to North American society in particular, or Western culture in general, solely through comparison and contrast to what "we" value and how "we" act. As Said (1979) points out, treating the "other" as opposite is the worst form of stereotyping, because it invalidates the "other" as a self-proclaiming entity. The formation of this false identity of Chinese students thus indicates a lack of understanding and validation of Chinese culture and the teaching methodology employed in the classroom.

Different culture worlds

Chinese culture has a great influence on the Chinese people today. While there are many ideologies that may have an influence, Confucian philosophy has a strong impact on the Chinese people's viewpoint, way of thinking and behaviors. Confucius' philosophy of learning, for example, can be summarized as "effortful learning, behavioral reform, pragmatic learning, acquisition of essential knowledge, and respectful learning” (Tweed \& Lehman, 2002. p. 91).

Confucius stressed the importance of hard work. He believed that one's success mainly came from hard work not ability. He also believed that "behavior reform is a central goal of education because virtuous behavior can ensure individual success and societal harmony” (p. 92). Confucius valued pragmatic learning. He viewed the goal of learning as to competently conduct oneself within a civil service job. He stressed the acquisition of essential knowledge and respectful learning. He taught his students to respect and obey authorities. He once said that "to honor those higher than ourselves is the highest expression of the sense of justice" (Confucius, 1947. p.332).

Chinese culture places an emphasis on harmony and respect for authorities. Therefore, Chinese students are usually reluctant to share their feelings or emotions, express their opinions or oppositions to anyone, especially to authority figures. Thus instead of emphasizing personal rights and assertive communication, Chinese students tend to emphasize the importance of patience, harmony, respect and deference. Chinese culture tends to place a high value on team efforts or collectivity whereas North American culture tends to emphasize individualism. Chinese students are also modest about their accomplishments. Many of them feel uncomfortable with the individualism and the competitiveness associated with the North American culture (Lin \& Yi, 1997). Or stated in another way: while individualism and competitiveness may exist in China; many students may feel uncomfortable with 
the degree of individualism and the competitiveness associated with the North American culture.

Chinese students at North American universities often struggle between the balance of acculturation and maintaining their own culture. The process of acculturation and adjustment can be stressful. The differences between the two cultures can cause a student to experience significant intrapersonal and interpersonal problems and conflicts. According to Lin and Yi (1997), many Chinese students experience the following: pressure from academic demands, language barriers, financial concerns, performance anxiety, depression, loneliness, homesickness, relationship problems, non-assertiveness, individualism and bicultural conflicts, stereotyping, prejudice, discrimination and paranoia.

\section{Different classroom teaching methods}

The discourse of participation is highly valued, promulgated and practiced by North American teachers (Cortazzi \& Jin, 1996). This discourse is often seen in China as exotic and students often become confused with what the teacher expects of them in a seemingly unsupportive environment where conversations, discussions, debates and participation become the dominant mode of teaching (Sun, 1990; Wan, 1997). Originating from the Western culture of learning, the discourse becomes problematic in the Chinese educational contexts, where authoritative discourse is stressed and the primary role of a teacher as an authority is to teach while the major role of a student is to receive, absorb, and digest the knowledge transmitted by the teacher (Cortazzi \& Jin, 1996; Craig, 1995; Wan, 1997).

$\mathrm{Fu}$ (1991) argues that the roles of the teacher are defined and interpreted differently in North American and Chinese cultures. In Chinese culture there is lack of a spirit of equality in classrooms. Teachers are regarded not only as authorities in their field of study but also as the students' moral mentor. In North American classrooms on the other hand, there is an equal relationship between teachers and students. So Chinese teachers are always very serious and focus on lecturing while North American teachers often use humor and varied, informal teaching methods in classroom. Difference in classroom teaching methodology has become the biggest cultural difference for Chinese students and North American teachers' different teaching methods cause considerable challenges for them in their classroom learning process (Chen, 1985; Upton, 1989). As identified in Huang's (2005) study, the following characteristics related to North American classroom teaching methodology negatively affects Chinese students' classroom learning: 1) too much group work and student participation; 2) failure 
to follow the textbook; 3) poor lecture organization, and lack of lecture summary in particular; and 4) lack of blackboard writing (Huang, 2005).

Those studies argue that Chinese students are not used to North American teaching methods and so they have difficulties in classroom learning, which implies that they would have no challenges at all if they familiarized themselves with North American classroom teaching methods. But if we take one step further to discuss this issue; it is actually a question of an unequal relationship between Chinese students and North American professors and peers.

First of all, we disagree with Fu's position that in North American classrooms, there is an equal relationship between teachers and students. In North American classrooms, there also exists inequality. North American professors have power or authority over Chinese students and North American students have more privileges than Chinese students.

Group work and student participation are the important modes of teaching in North American classrooms. In considering the use of group work and student participation in the classroom, we need to ask the following questions: what are students really doing and how do they feel about working in groups? Are these methods used correctly? And which students are really participating? Our personal conversations with Chinese students about their own North American classroom learning experience show that there are many complaints from Chinese students about student participation and group work in North American classrooms. For example, some North American students waste other students' time by just talking about nonsense in the classroom and the teacher seems to enjoy this meaningless talk. Sometimes group-work is not used correctly by the North American professors either. For example, Chinese students are often grouped with Chinese students or other ESL students and their "otherness" or different identity is further confirmed in the classroom. Whether this is a North American uniqueness is unclear. Also, while this may have some positive benefits; it can also lead to isolation.

The structuring or organization of a lecture is an essential aspect of its comprehensibility, and effective lecture preparation and delivery can be arranged under the following three stages: 1) the beginning; 2) the body; and 3) the closing (Chaudron \& Richards, 1986; Diamond, Sharp, \& Ory, 1983). In the beginning stage, the lecturer usually relates lecture content to previous class material, mentions the background of the current lecture, or gives students a brief introduction of the content of the current lecture. In the body of the lecture, there is some flexibility for the lecturer to present the content. The lecturer can either decide the main points and explain them clearly to the listeners or organize the material in some logical order such as "cause-effect," "time-sequential," etc. 
During the lecture the lecturer may ask some questions to check on students' understanding of the lecture or ask them to make their comments. In the last stage of the lecture, the lecturer may briefly summarize the content of the lecture or reemphasize what he expects the students to learn from the lecture. But many Chinese students comment that their North American teachers, compared with their teachers in China, are poorer classroom managers or organizers, and they do not usually know how to effectively teach their classes (Huang, 2005; Upton, 1989). Chinese students often get confused about what they should learn about a lecture. Upton (1989) interviewed a Chinese student and made the following comments:

One Chinese student I interviewed said that she felt frustrated because she was not always sure what exactly the teachers wanted her to know. When she asked a teacher to help her out, his response of "You don't have to understand everything” really confused her (Upton, 1989, p. 25).

To sum up, North American professors have the power to choose what to teach, and how to teach in particular. When they are choosing a North American method to teach a class, they actually ignore their Chinese students, the language minority students in the classroom. North American professors do not intentionally ignore Chinese students. They are lacking the knowledge, resources, or expertise to include Chinese cultural components and Chinese students in the classroom. As a result, Chinese students' prior educational experience is devalued and their voices about their learning strategies and preferences are not heard. Therefore they are not offered equal opportunities and, ultimately, they can hardly gain equal in-group memberships of the classroom learning community as their North American peers.

\section{CHINESE STUDENTS IN CLASSROOM COMMUNITIES}

In North American classrooms, teachers often ask students to discuss current events; comment on TV shows; and write newspaper article critiques (Alvermann, Moon, \& Hagood, 1999; Buckingham, 1998; Huang, 2005; Stevens, 2001). North American students have grown up in this cultural context and established their in-group membership with other North Americans. They can talk about their past social experience. They have no difficulty in understanding classroom discussions and sharing their own social experience. Chinese students, however, have not grown up in this cultural context; surely have difficulty in comprehending lectures at North American classrooms. According to a study by Huang (2005) on the challenges experienced by Chinese students in understanding academic lectures at an American university, about $80 \%$ of the 
participants comment that their American teachers use examples or situations that happen only in American culture while lecturing and strongly agree that the use of unfamiliar examples or situations caused great challenges for them in understanding class lectures. That is to say, Chinese students have great difficulty being included in the social worlds of their North American counterparts within the classroom.

The use of examples or situations that happen only in North American culture in the classrooms delights only the North American students, allowing them to display and construct their "identities, knowledge, interests, past experiences, sense of humor, and sociocultural affiliations (Duff, 2002).” However, it excludes Chinese students from the classroom community. They are treated as outsiders of the classroom learning community. In the classroom, Chinese students do not have equal opportunities to speak and they speak only when they are asked to. Having fewer North American cultural reference points that might help their comprehension, they usually have considerable challenges understanding what their North American classmates are talking about. But if Chinese students ask for explanations and try to join the discussions in class the North Americans might further confirm their difference and "otherness". Silence protects them from humiliation but it does not help them gain access to the valued cultural capital and practices of their North American peers. So in class Chinese students are seen as marginal participants, shy, communicatively incompetent, and uninterested in the local culture, with identities thus defined by their nonparticipation and disengagement (Wenger, 1998). On the contrary, Chinese students have their own senses of humor, their culture alignments, their talents, their social affiliations, and intelligence. If all those are not valued, the students become invisible and inaccessible to others in North American classroom communities.

\section{CHINESE STUDENTS IN OUTSIDE-CLASSROOM COMMUNITIES}

Social communicative competence is conceptualized as a multitude of social communication skills that increase a person's social communicative effectiveness. These communication skills include listening, initiating social contacts, asking and responding to questions, or expressing one's point of view without offending others (Mathur \& Rutherford, 1994). A person with those social communication skills is capable of initiating and maintaining positive social interactions, developing friendships, establishing collaborative networks, and coping effectively with their social environment. In contrast, lack of social communication skills has been identified as one of the major predictors of low 
self-esteem, peer rejection, social maladjustment, mental health problems, and delinquency (Asher \& Wheeler, 1985; Elliott \& Gresham, 1993).

What is the content of North American students' social communications in outside-classroom communities? Much of what students read, write, and talk about out of school today is culture, which means North American students' social life is linked to North American culture (Asselin, 2001).

Forming and maintaining friendships, taking the initiative in conversations and a willingness to converse with native North American students are all important to Chinese students' social communications in outsideclassroom communities, according to Myles, Qian, and Cheng (2002). Chinese students, however, have not grown up in the North American cultural context, so they obviously will have difficulty in communicating and establishing in-group memberships with their North American peers. In outside-classroom communities, Chinese students find it difficult to socialize themselves with North American people due to their lack of North American culture. They share no common interest with North Americans and thus can hardly make real friends with them (Feng, 1991; Sun and Chen, 1997).

The results of Feng's (1991) study indicate that Chinese students experience peer rejection and report feelings of loneliness and social isolation at North American universities. That they share few or no common topics and interests with North American students is a considerable challenge for Chinese students at North American universities. North Americans often talk about football and baseball, for example. But Chinese students have no idea about North American sports. Due to two different cultures, Chinese students often avoid participating in social activities in North America. They find it hard to make real North American friends. There is a lack of mutual understanding between Chinese students and their North American peers.

In addition, in the same study Feng (1991) talks about holidays as an important part of North American culture. North Americans and Chinese people have very different holidays to celebrate each year. In North America, Christmas, Thanksgiving, Easter, and Halloween are very important holidays. North American people have different traditions for different holidays and their ways to celebrate different holidays are also different. While in China, people celebrate the Spring Festival, the Dragon Boat Festival, the Mid-Autumn Festival, and some other festivals. When the North Americans are celebrating their holidays, Chinese students cannot feel that kind of holiday atmosphere and they often isolate themselves from the North Americans. When Chinese holidays come, they have to go to school. They are also far from their parents and friends. They cannot feel the right kind of Chinese holiday atmosphere either. In that sense, 
Chinese students at North American universities cannot really enjoy any kind of holidays, which increases their homesickness and isolation.

Finally, Feng (1991) mentions religion as another big problem that bothers Chinese students in North America. In China people are educated not to believe in God, while in North America religion is an important part of culture. Chinese students are very much concerned about how to deal with religion in North America. In some parts of North America, going to church is the only thing people do on Sundays. The following report by a Chinese student reflects some Chinese students' concerns about religion in North America:

This city is very religious. But in China, few people are interested in religion. We grew up in a communist society. We have been educated by communist doctrine since we were little. Of course many people here are friendly, and willing to help foreign students. But, they often talk about God, and try to convince you to believe in God, which make many of us uncomfortable...

Although host families can help you understand American culture. I think they are often too religious. They are so much interested in religion. They give you Bible, and want you to spend time reading the Bible. On Sundays, they take you to local church. I don't like that (Feng, 1991, p. 10)

Feng's (1991) study analyzes how cultural differences create challenges for Chinese students in their academic learning process at North American universities. But the analysis is limited to very surface understanding of the role of North American culture in Chinese students' learning process in North America. For example, Feng comments that Chinese students have difficulties in communicating socially with their North American peers outside the classroom and their difficulties come from their unfamiliarity with the North American culture, possibly suggesting that Chinese students should totally forget their Chinese culture and soon become North Americanized. The North American culture actually plays a very negative role in Chinese students' outside classroom social communications with North American people. North American culture, as the dominant culture, excludes Chinese students as a group of different people from "other" places. Chinese culture is not very much valued in North America. As a matter of fact, Chinese students at North American universities can find themselves deprived of their basic rights as human beings: the right to make true friends, the right to enjoy holidays, and the right to be treated equally as members of the community, not as different "others". It can be argued that NorthAmerican academia is not culturally inclusive enough to the Chinese students in 
North America who come from a totally different culture. There is evidence that Chinese students will find it difficult to make true friends and enjoy holidays as they could do while in China except with other Chinese students. In this sense, their rights have been deprived.

\section{CONCLUSION}

It can be argued that Chinese students are from a very different cultural and linguistic context. North American educators should try to create a more inclusive learning environment for this group of culturally and linguistically different students (Duff, 2002). There are many challenges faced by Chinese students in North America. It has been demonstrated that linguistic and cultural factors affect Chinese students' academic studies: their unfamiliarity with the North American culture; their lack of North American academic background; their lack of academic study skills, and their inadequate English proficiency all add to their challenges. One should note that the use of examples or situations that happen only in the North American culture should not be used excessively in the classroom. Rather, these examples or situations should be part of an inclusive multicultural perspective. Further, we need to help Chinese students understand North American culture and encourage them to actively participate in classroom discussions. We should also encourage Chinese students to bring elements of their culture into classroom discussions. By doing this, they can gradually gain equal in-group memberships as their North American peers.

* Throughout this paper, the term 'Chinese students' refer to 'Chinese graduate students who are from the People’s Republic of China and currently studying at North American universities.' 


\section{References}

Alvermann, D., Moon, J., \& Hagood, M. (1999). Popular culture in the classroom. Newark, DE \& Chicago, IL: International Reading Association and the National Reading Conference.

Asher, S.R., \& Wheeler, V.A. (1985). Children's loneliness: A comparison of rejected and neglected peer status. Journal of Consulting and Clinical Psychology, 53, 500-505.

Asselin, M. (2001). Teaching literacy from and with popular culture. Teacher Librarian 28, 47-49.

Biggs, J.B. (1987). Student approaches to learning and studying. Melbourne: Australian Council for Educational Research.

Buckingham, D. (Ed.). (1998). Teaching popular culture: Beyond radical pedagogy. London: University College Press.

Canadian Bureau for International Education. (2002, April 15). International student numbers hit record high, but Canada offers dwindling support for African students. Retrieved October 28, 2002 from: http://www.cbie.ca/news/index_e.cfm?folder=releases\&page=rel_2002-04-15_e

Chaudron, C., \& Richards, J.C. (1986). The effect of discourse markers on the comprehension oflectures. Applied Linguistics, 7, 113-127.

Chen, C. P. (1999). Common stressors among international college students: Research and counseling implications. Journal of College Conseling, 2, 49-65.

Chen, T. H. (1985). Cultural differences in classrooms: A comparison of Chinese and US schooling. Unpublished manuscript.

Confucius. (1947). The wisdom of Confucius. In S. Commins \& R. N. Linscott (Eds.), Man and man: The social philosophers. New York: Random House. pp. 323-358. (Original work published ca. 479 B.C.E.)

Cortazzi, M., \& Jin, L.X. (1996). Cultures of learning: Language classrooms in China. In H. Coleman (Ed.), Society and the language classroom (pp. 169-206). Melbourne: Cambridge University Press.

Craig, B.A. (1995). Boundary discourse and the authority of knowledge in the second-language classroom: A social-constructionist approach. In J.E. Alatis et al., (Eds.), Georgetown University round table on language and linguistics, 1995. Washington D. C.: Georgetown University Press. pp. 40-54.

Diamond, N.A., Sharp, G. \& Ory, J.C. (1983). Improving your lecturing. Office of Instructional and Management Services, University of Illinois at Urbana-Champaign.

Duff, P.A. (2002). Pop culture and ESL students: Intertextuality, identity, and participation in classroom discussions. Journal of Adolescent \& Adult Literacy, 45, 482-487.

Elliott, S.N., \& Gresham, F.M. (1993). Social skills interventions for children. Special Issue: Social-skills and intervention with children and adolescents. Behavior Modification, 1, 287-313.

Feng, J.H. (1991). The adaptation of Students from the People's Republic of China to an American Academic Culture. Reports (ERIC Document Reproduction Service No. ED 329 833).

Fu, D.L. (1991). A process classroom through the eyes of an outsider. Language Arts, 68, 121-123.

Ghosh, R. (2000). Identity and social integration: Girls from a minority ethno-cultural group in Canada. McGill Journal of Education 35, 279-296.

Huang, J. (2004). Voices from Chinese students: Professors' use of English affects academic listening. College Student Journal, 38(2), 212-223.

Huang, J. (2005). Challenges of academic listening in English: Reports by Chinese students. College Student Journal, 39(3), 553-569.

Huang, J. (2006). English abilities for academic listening: How confident are Chinese students? College Student Journal, 40(1), 218-226.

Huang, J., \& Klinger, D. (2006). Chinese graduate students at North American universities: Learning challenges and coping strategies. The Canadian and International Education Journal, 35(2), 48-61.

Institute of International Education. (2001, June 15). 98/99 opendoors on the Web. [Selections from the book], New York. Retrieved June 15, 2002 from the World Wide Web: http://www.opendoorsweb.org/Lead\%20Stories/international_studs.htm

Kember, D., \& Gow, L. (1991). A challenge to the anecdotal stereotype of the Asian student. Studies in Higher Education, 16, 117-128.

Krugly-Smolska, E. (1997). Global and local challenges of/to the post-modern: Implications for education. Canadian and International Education, 26 (2), 1-7.

Lin, J.G., \& Yi, J.K. (1997). Asian international students’ adjustment: Issues and program suggestions. College 
Student Journal, 31, 473-479.

Liu, D.L. (1994). Deep sociocultural transfer and its effect on second language speakers' communication. Paper presented at the annual meeting of the Teachers of English to Speakers of Other Languages, Maltimore, MD.

Mathur, S.R., \& Rutherford, R.B. (1994). Teaching conversational skills to delinquent youth. Behavioral Disorders, 19, 294-305.

Marton, F., Dall'Alba, G., \& Kun, T.L. (1996). Memorizing and understanding: The keys to the paradox? In D.A. Watkins \& J.B. Biggs (Eds.), The Chinese learner: Cultural, psychological, and contextual influences. Hong Kong: Comparative Education Research Center. pp. 69-84.

Marton, F., \& Saljo, R. (1976). On qualitative differences in learning: Outcome and process. British Journal of Educational Psychology, 46, 4-11.

Myles, J., Qian, J., \& Cheng, L. (2002) International and new immigrant students' adaptations to the social and cultural life at a Canadian university. In S. Bond \& C. Bowry (Eds.) Connections \& Complexities: The Internationalization of Canadian Higher Education, Occasional Papers in Higher Education, Vol. 11, Winnipeg, Center for Research and Development in Higher Education.

Pratt, D.D., \& Wong, K.M. (1999). Chinese conceptions of "effective teaching" in Hong Kong: Towards culturally sensitive evaluation of teaching. International Journal of Lifelong Education, 18, 241-258.

Reber, A. (1985). The Penguin dictionary of psychology. Harmondsworth: Penguin.

Said, E.W. (1979). Orientalism. New York: Vintage Books.

Samuelowicz, K. (1987). Learning problems of overseas students: Two sides of a story. Higher Education Research and Development, 6, 121-134.

Stevens, L. (2001). South Park and society: Instructional and curricular implications of popular culture in the classroom. Journal of Adolescent \& Adult Literacy, 44, 548-555.

Sun, G. Y. (1990). English teaching in China. ELT Newsletter: Teaching English in China, 21, 76-82.

Sun, W., \& Chen, G.M. (1997). Dimensions of difficulties Mainland Chinese students encounter in the United States. Paper presented at the $6^{\text {th }}$ International Conference in Cross-Cultural Communication, Tempe, AZ. (ERIC Document Reproduction Service No. ED 408 635)

Taylor, C. (1992). The politics of recognition. In A. Gutman (Ed.), Multiculturalism and the "politics of recognition." Princeton, New Jersey: Princeton University Press. pp. 25-74.

Tweed R.G., \& Lehman, D.R. (2002). Learning considered within a cultural context. American Psychologist, 57(2) 89-99.

Upton, T.A. (1989). Chinese students, American universities, and cultural confrontation. MinneTESOL Journal, 7, 9-28.

Wan, Z.X. (1997). Observation on teaching style of native-speaking teachers in Chinese ELT classrooms. ELT Newsletter: Teaching English in China, 29, 101-104.

Wenger, E. (1998). Communities of practice: Learning, meaning, and identity. Cambridge, England: Cambridge University Press.

Zhong, M. (1996). Chinese students and scholars in the US: An intercultural adaptation process. Paper presented at the $82^{\text {nd }}$ Annual Meeting of the Speech Communication Association, San Diego, CA. (ERIC Document Reproduction Service No. ED 406 704)

Jinyan Huang is an assistant professor in TESOL and Assessment at the College of Education of Niagara University. He can be reached at jhuang@niagara.edu.

Peter Alexander Cowden is an assistant professor at the College of Education of Niagara University; he focuses on learning and affective issues and teaching students with exceptional needs. He can be reached at pcowden@niagara.edu. 